\title{
Efektivitas Air Alkali Terionisasi Sebagai Antioksidan Terhadap Penurunan Kadar Asam Urat Pada Mencit Jantan (Mus musculus)
}

\section{The Effectiveness Of Ionized Alkaline Water As An Anti-Oxidant Toward Decreased Levels Of Uric Acid In Male Mice (Musmuculus)}

\author{
Suhada Adriyan ${ }^{1}$, Noviana Iksir ${ }^{2}$, Ade Sukma Hamdani ${ }^{3}$ Dedent Eka Bimmaharyanto $\mathrm{S} .{ }^{4} \mathrm{Ni}$ \\ Komang Wijiani Yanti ${ }^{5}$ \\ Email: adriyan_suhada@yahoo.com¹, ade.sukmahamdani18@gmail.com ${ }^{3}$, dedenthariyanto@gmail.com ${ }^{4}$, \\ wijiani16@gmail.com ${ }^{5}$ \\ ${ }^{12345}$ Program Studi S1 Farmasi Universitas Nahdlatul Ulama NTB \\ Jl.Pendidikan No 06 Mataram Nusa Tenggara Barat
}

\begin{abstract}
Abstrak. Asam urat adalah produk akhir katabolisme purin atau degredasi asam nukleat dari sisa makanan yang kita konsumsi. Pada manusia dikatakan Hiperurisemia apabila terjadi peningkatan kadar asam urat darah serum lebih dari $7 \mathrm{mg} / \mathrm{dl}$ pada lelaki dan lebih dari $6 \mathrm{mg} / \mathrm{dl}$ pada wanita. Untuk mencit dikatakan hiperurisemia bila kadar asam uratnya 1.7-3.0 mg/dl dengan kadar asam urat normal 0.5-1.4 mg/dl. Tujuan penelitian ini adalah untuk mengetahui "Evektivitas air alkali terionisasi sebagai anti oksidan terhadap penurunan kadar asam urat pada mencit jantan (mus muculus)" Penelitian ini dilakukan dengan metode eksperimental laboratorium, dimana mencit yang menjadi hewan uji diinduksi dengan potasium oksonat 300 $\mathrm{mg} / \mathrm{BB}$. Control positif dengan memberikan allopurinol $100 \mathrm{mg} / \mathrm{kg} \mathrm{BB}$, kontrol negative $0.2 \mathrm{ml} / \mathrm{g} \mathrm{BB}$. Sementara perlakuan adalah dengan memberikan Air Alkali (pH 8.5, 9.0, 9.5 dan 11.5 0. Sebanyak 0,0284 $\mathrm{ml} / \mathrm{g} \mathrm{BB}$ ) setelah diberikan perlakuan kadar asam urat dicek dari jam 1.2.3 dan 4 sebagai data. Hasil penelitian menunjukkan bahwa terdapat perubahan rata-rata kadar asam urat pada kelompok 1 (kontrol negatif), $0.97 \%$ pada kelompok 2 (control positif), $0.68 \%$ padakelompokuji 3 (PH8,5), 0.93\% kelompok uji 4 (PH 9.0). 0.96\% kelompok uji 5 Data (PH 9.5). 0.93\% dan kelompok terakhir kelompok 6 (PH 11.5) sebesar $0.72 \%$. berdasarka npenelitian yang dilakukan dapat disimpulkan bahwa air alkali terionisasi mempunyai aktivitas anti hiperurisemia. Aktivitas tersebut signifikan pada $\mathrm{pH}$ yang digunakan ( $\mathrm{pH}$. 11.5) dengan persen penurunan sebesar $0.72 \%$ dibandingkan dengan $\mathrm{pH}$ yang lain.
\end{abstract}

Kata kunci: Kadar Asam Urat Darah, Air Alkali Terionisasi. Mencit Jantan (Mus musculus).

Abstract.Uric acid is the end product of purine catabolism or degradation of nucleic acids from the food we consume. In humans it is said to be hyperuricemia when an elevated serum blood uric acid level is more than $7 \mathrm{mg} / \mathrm{dl}$ in men and more than $6 \mathrm{mg} / \mathrm{dl}$ in women. For mice it is said hyperuricemia when uric acid levels are 1.7-3.0 $\mathrm{mg} / \mathrm{dl}$ with normal uric acid levels $0.5-1.4 \mathrm{mg} / \mathrm{dl}$. The purpose of this study was to determine "The effectiveness of ionized alkaline water as an anti-oxidant toward decreased levels of uric acid in male mice (musmuculus)" This research was conducted by laboratory experimental methods, in which mice that became test animals were induced with potassium oxonate $300 \mathrm{mg} / \mathrm{BW}$. Positive control by giving allopurinol $100 \mathrm{mg} / \mathrm{kg}$ body weight, negative control $0.2 \mathrm{ml} / \mathrm{g}$ body weight. While the treatment is to

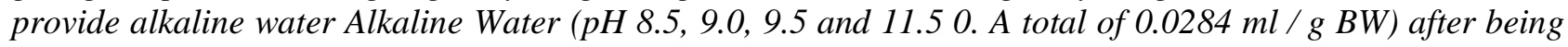
given the treatment of uric acid levels checked from hours 1.2.3 and 4 as data. The results showed that there were changes in average uric acid levels in group 1 (negative control), $0.97 \%$ in group 2 (positive control), $0.68 \%$ in test group 3 ( $p H$ 8.5), $0.93 \%$ test group 4 ( $p H 9.0$ ). $0.96 \%$ test group 5 data ( $p H$ 9.5). $0.93 \%$ and the last group group 6 ( $p H$ 11.5) was $0.72 \%$. Based on research conducted it can be concluded that ionized alkaline water has anti-hyperuricemia activity. The activity is significant for the $\mathrm{pH}$ used (pH. 11.5) with a percent decrease of $0.72 \%$ compared to other $\mathrm{pH}$.

Keywords: Blood Uric Acid Levels, Ionized Alkaline Water. Male Mouse (Mus musculus).

\section{PENDAHULUAN}

Kesadaran masyarakat akan pentingnya kesehatan mengalami peningkatan, namun seiring dengan hal tersebut juga berkembang berbagai jenis penyakit akibat perubahan gaya hidup. Seiring dengan perkembangan ilmu pengetahuan dan teknologi di era digital serta berubahnya gaya hidup dimasyarakat berdampak munculnya berbagai penyakit degeneratif yang membahayakan. 
Salah satu gangguan kesehatan yang paling banyak muncul adalah peningkatan jumlah penyakit asam urat. Asam urat merupakan salah satu dari beberapa penyakit yang sangat membahayakan karena bukan hanya mengganggu kesehatan tetapi juga dapat mengakibatkan cacat pada fisik.

Penyakit asam urat adalah istilah yang sering digunakan untuk menyebut salah satu jenis penyakit rematik artikuler (Utami, 2003). Dikatakan Hiperurisemia apabila terjadi peningkatan kadar asam urat darah serum lebih dari $7 \mathrm{mg} / \mathrm{dl}$ pada lelaki dan lebih dari $6 \mathrm{mg} / \mathrm{dL}$ pada wanita (Soeroso dkk., 2011).

Kadar asam urat darah di tentukan oleh keseimbangan antara produksi dan ekskresi asam urat kejadian asam urat juga di sebabkan oleh beberapa faktor, antara lain: genetik, jenis kelamin, berat badan (Price SA, 2008). Penyakit ini juga berkaitan erat dengan ginjal, karena ginjal merupakan suatu organ yang berfungsi sebagai tempat pembuangan asam urat yang berlebihan. Ketika ginjal tidak mempunyai kekuatan untuk membuang asam urat yang berlebihan, maka hal ini yang menjadi salah satu penyebab terbentuknya asam urat (Asaidi, 2010)

Kemajuan ilmu pengetahuan dan teknologi pada bidang ilmu kefarmasian menimbulkan perkembangan dan inovasi penemuan obat baru yang berasal dari obat tradisional mulai berkembang pesat. Pengobatan yang cukup dikenal dalam dunia kesehatan adalah pengobatan sintetik maupun alamiah, contoh obat sintetik yang umumnya dikonsumsi untuk mengobati kelebihan asam urat darah adalah allopurinol yang bekerja dengan cara menginhibisi aktivitas xantin oksidase, xantin oksidase mengkatalisis oksidasi xantin menjadi asam urat (Gunawan. $G$ 2007). Adapun pengobatan tradisional lainya seperti infusa daun salam, ekstrak daun sirsak. Dimana pada pemeberian sediaan infusa daun salam terbukti dapat menurunkan kadar asam urat darah pada mencit yang diinduksi dengan potassium oksanat (Ariyanti dkk. 2007).

Saat ini banyak beredar air alkali yang dijadikan trend medikasi pengobatan oleh masyarakat. Dalam hal ini data dari BPOM tahun 2017 menyebutkan terdapat 10 air kemasan di Indonesia yang sudah terdaftar. Air alkali yang sering dikonsumsi oleh masyarakat dengan berbagai merk banyak digunakan untuk tujuan kesehatan dengan harga yang bervariasi, yang diklaim dapat memperbaiki kondisi seperti asam urat, diabetes militus dan diare lain sebagainya.

Masyarakat khususnya Lombok Tengah bagian selatan telah menggunakan air alkali sebagai obat alternatif untuk penyembuhan berbagai jenis penyakit diabetes dan asam urat. Berdasarkan penelitian yang di lakukan oleh Edy dkk (2018) menyatakan bahwa mengkonsumsi air alkali dapat menurunkan kadar glukosa darah. Serta penelitian yang dilakukan oleh Septiandu dkk pada tahun 2017 terbukti air alkali dengan $\mathrm{Ph} 9$ dapat menurunkan kadar kolesterol.

Berdasarkan penelitian tersebut dan didukung pengalaman dari masyarakat minimnya dasar ilmiah tentang pengaruh air alkali terionisasi terhadap kejadian asam urat, penulis merasa perlu melakukan penelitian yang ditunjukan untuk mengetahui "apakah air alkali mempunyai efektivitas dalam menurunkan kadar asam urat pada mencit jantan (Mus Musculus)"

\section{METODE PENELITIAN}

Jenis Penelitianini merupakan suatu penelitian eksperimental laboratorium dengan mengunakan desain penelitian yaitu uji anova one way pengumpulan data berdasarkan hasil eksperimen yang dilakukan.

\section{Alat Dan Bahan}

a. Alat yang digunakan dalam penelitian ini sebagai berikut :

1) Timbangan digital

2) Timbangan analitik

3) Sonde oral

4) Spuit terumo

5) Strip asam urat)

6) Mortir dan stamper

7) Timbangan Analitik

8) Kertas $\mathrm{pH}$

9) Batang pengaduk

10) Pinset

11) Kapas

12) Handscoon dan masker

13) Alat ukur asam urat 
b. Bahan yang digunakan dalam penelitian ini sebagai berikut :

1) Aquadest

2) air alkali terionisasi dari mesin kangen water tipe levluk SD 501

3) bahan kimia yang di gunakan yaitu kalium oksonat (penginduksi), $\mathrm{Na}$ CMC, allopurinol dan

4) hewan uji yang di gunakan adalah mencit jantan dengan berat badan sekitar 20-30 gram dan berumur 2-3 bulan

5) pakan mencit (pellet)

6) serbuk kayu

7) kapas alcohol

8) aqua pro injeksi

9) akuades dan air hangat.

\section{Persiapan Hewan Uji}

Hewan uji didapatkan dari fakultas kedokteran Universitas Matara, Perlakuan pada hewan uji yang digunakan dalam penelitian ini adalah mencit putih jantan mus musculus dengan berat rata-rata 20-30 gram dan berumur 2-3 bulan. Hewan uji tersebut diadaptasikan terlebih dahulu dengan lingkungan penelitian selama 1 hari dan dipuasakan \pm 8 jam sebelum penelitian dimulai dengan di beri air minum ad libitum (secukupnya).

\section{Penentuan Dosis}

a. Allopurinol yang digunakan adalah $100 \mathrm{mg} / \mathrm{kgBB}$ dosis manusia

b. Dosis potasium oksonat yang digunakan adalah $300 \mathrm{mg} / \mathrm{kgBB}$. dan

c. Dosisair alkali per pH 0,0284 $\mathrm{ml} / \mathrm{gBB}$.

\section{Pemilihan Dan Penyiapan Air Alkali}

Air alkali yang di gunakan dalam penelitian ini adalah air alkali terionisasi dari mesin kangen water tipe leavlux sd 501 dengan pemilihan $\mathrm{Ph} 8.5, \mathrm{Ph} 90, \mathrm{Ph} 9.5, \mathrm{Ph}$ 11.5.

\section{Uji Efek Anti Hiperurisemia}

Mencit dibagi menjadi 6 kelompok, kelompok kontrol dan kelompok hewan uji, yang masing-masing kelompok terdiri atas 3 ekor mencit kelompok kontrol negatif yang diberi aquadest. Kelompok kontrol positif allopurinol $100 \mathrm{mg} / \mathrm{kgBB}$ dan kelompok uji terdiri atas kelompok mencit yang diberi air

alkali ( $\mathrm{pH} 8.5, \mathrm{pH} 9.0, \mathrm{pH} 9.5$ dan $\mathrm{pH} 11.5$ sebanyak $0.0284 \mathrm{ml} / \mathrm{kg} \mathrm{BB}$ ).

Hewan uji dibagi berjumlah 24 ekor dibagi menjadi 6 kelompok sama banyak yaitu;

1) Kelompok I: kontrol negatif hiperurisemia (normal), diberi aqua proinjeksi $0.5 \mathrm{ml} / 20 \mathrm{~g}$ BB secara oral.

2) Kelompok II: kontrol positif, diberi allopurinol dosis $100 \mathrm{mg} / \mathrm{kg}$ BB secara oral yang diinduksi potasium oksonat dosis 300 $\mathrm{mg} / \mathrm{kg} \quad \mathrm{BB} \quad(0.5 \mathrm{ml} / \mathrm{g} \quad \mathrm{BB})$ secara intraperitonial 1 jam setelah perlakuan.

3) Kelompok III: diberi potasium oksonat dosis $300 \mathrm{mg} / \mathrm{kg} \mathrm{BB}(0.5 \mathrm{ml} / \mathrm{g} \mathrm{BB})$ secara intraperitoneal danair Alkali $\mathrm{Ph} 8.5$ dosis $0,0284 \mathrm{ml} / \mathrm{g}$ BB secara peroral 1 jam setelah perlakuan.

4) Kelompok IV: diberi potasium oksonat dosis $300 \mathrm{mg} / \mathrm{kg}$ BB $(0.5 \mathrm{ml} / \mathrm{g} \mathrm{BB})$ secara intraperitoneal dan diberi air Alkali $\mathrm{Ph} 9.0$ dosis $0,0284 \mathrm{ml} / \mathrm{g}$ BB secara peroral 1 jam setelah perlakuan.

5) Kelompok V: diberi potasium oksonat dosis $300 \mathrm{mg} / \mathrm{kg} \mathrm{BB}(0.5 \mathrm{ml} / \mathrm{g} \mathrm{BB})$ secara intraperitoneal dan diberi air alkali $\mathrm{Ph}$ 9.5. dosis $0,0284 \mathrm{ml} / \mathrm{g}$ BB secara peroral $1 \mathrm{jam}$ setelah perlakuan.

Kelompok VI: diberi potasium oksonat dosis $300 \mathrm{mg} / \mathrm{kg}$ BB $(0.5 \mathrm{ml} / \mathrm{g} \mathrm{BB})$ secara intraperitoneal diberi air alkali $\mathrm{Ph} 11.5$, dosis $0,0284 \mathrm{ml} / \mathrm{g}$ BB secara peroral 1 jam setelah perlakuan.

\section{Analisis data}

Data yang diperoleh dianalisis mengunakan uji statistik one way anova dengan tingkat kepercayaan $95 \%$ untuk perbedaan kadar masing masing kelompok perlakuan.

\section{HASIL DAN PEMBAHASAN}

Berikut ini hasil pengukuran kadar asam urat darah mencit yang diinduksi dengan potassium oksonat.

\begin{tabular}{|c|c|c|c|c|}
\hline \multirow[t]{2}{*}{ kelompok } & \multicolumn{4}{|c|}{$\begin{array}{c}\text { Kadar Asam Urat Darah Mencit } \\
(\mathrm{mg} / \mathrm{dl})\end{array}$} \\
\hline & $\begin{array}{c}\text { Tikus } \\
1\end{array}$ & $\begin{array}{l}\text { Tikus } \\
2\end{array}$ & $\begin{array}{c}\text { Tikus } \\
3\end{array}$ & $\begin{array}{c}\text { Rata-rata } \\
\% \\
\text { penurunan }\end{array}$ \\
\hline k- & 25.8 & 37 & 29.5 & $0.97 \%$ \\
\hline $\mathbf{K}+$ & 24.1 & 24.2 & 40.2 & $0.68 \%$ \\
\hline Ph 8.5 & $22 \ldots 9$ & 27.8 & 24.8 & $0.93 \%$ \\
\hline Ph 9.0 & 524.6 & 23.3 & 32 & $0.96 \%$ \\
\hline Ph 9.5 & 36.1 & 24.5 & 36.1 & $0.93 \%$ \\
\hline Ph. 11.5 & 34.3 & 30.4 & 22.5 & $0.72 \%$ \\
\hline
\end{tabular}


Tabel 1. Kadar asam urat mencit setelah diinduksi pada jam 1.2.3.dan 4.

\section{Pembahasan}

\begin{tabular}{|c|c|c|c|}
\hline $\begin{array}{l}\text { Levene } \\
\text { Statistic }\end{array}$ & df1 & $\mathrm{df} 2$ & Sig. \\
\hline 1.713 & 5 & 12 & .206 \\
\hline
\end{tabular}

Tabel 2. Uji homogenitas

Kesimpulan dari uji homogenitas dari perhitungan di atas didapat tabel di atas memberikan nilai levene statistic sebesar 1,713 dengan signifikansi sebesar 0,206 (> 0,05). Hasil tersebut menunjukkan bahwa tidak terdapat perbedaan varians yang signifikan pada distribusi data atau dapat diinterpretasikan bahwa data telah terdistribusi secara homogen. Dengan demikian uji homogenitas memenuhi asumsi yang diperlukan pada uji ANOVA.

\begin{tabular}{|l|r|r|r|r|r|}
\hline & \multicolumn{1}{|c|}{$\begin{array}{c}\text { Sum of } \\
\text { Squares }\end{array}$} & \multicolumn{1}{c|}{ df } & Mean Square & F & Sig. \\
\hline Between Groups & 2.525 & 5 & .505 & .317 & .893 \\
Within Groups & 19.101 & 12 & 1.592 & & \\
Total & 21.626 & 17 & & & \\
\hline
\end{tabular}

Tabel 3. Uji anova

Menguji apakah keenam sampel mempunyai rata rata yang sama atau berbeda pada dasar pengambilan keputusan dalam analisis anova:

1. Jika nilai signifikasi (sig) $>0,05$ maka rata-rata sama

2. Jika nilai signifikasi (sig) $<0,05$ maka rata-rata berbeda

Dengan terpenuhinya uji normalitas, maka berikut adalah pengujian hipotesis $\mathrm{Ha}$ pada penelitian ini.

Tabel di atas memberikan nilai $\mathrm{F}$ hitung sebesar 0,317 dengan signifikansi sebesar $0,893 \quad(>0,05)$. Berarti tidak terdapat perbedaan yang signifikan antara kelompok kontrol dengan kelompok perlakuan. Hal ini mengindikasikan adanya penolakan untuk hipotesis Ha dalam penelitian ini.

\begin{tabular}{|c|c|c|c|c|c|c|}
\hline \multirow[b]{2}{*}{$\begin{array}{l}\text { (I) } \\
\text { Perlak } \\
\text { uan }\end{array}$} & \multirow[b]{2}{*}{$\begin{array}{l}\text { (J) } \\
\text { Perlak } \\
\text { uan }\end{array}$} & \multirow[b]{2}{*}{$\begin{array}{c}\text { Mean } \\
\text { Difference (I- } \\
\mathrm{J})\end{array}$} & \multirow[b]{2}{*}{ Std. Error } & \multirow[b]{2}{*}{ Sig. } & \multicolumn{2}{|c|}{$95 \%$ Confidence Interval } \\
\hline & & & & & Lower Bound & Upper Bound \\
\hline \multirow[t]{5}{*}{1} & 2 & .25333 & 1.03012 & .810 & -1.9911 & 2.4978 \\
\hline & 3 & 1.12000 & 1.03012 & .298 & -1.1244 & 3.3644 \\
\hline & 4 & .82667 & 1.03012 & .438 & -1.4178 & 3.0711 \\
\hline & 5 & 64000 & 1.03012 & .546 & -1.6044 & 2.8844 \\
\hline & 6 & .34000 & 1.03012 & .747 & -1.9044 & 2.5844 \\
\hline
\end{tabular}

Tabel 4. Post Hoc Test
Tabel di atas menunjukkan bahwa tidak terdapat signifikansi yang berada di bawah 0,05 . Hal ini menunjukkan bahwa tidak ada perbedaan yang signifikan antara kelompok pengukuran kadar asam urat. Hasil ini memperkuat indikasi pengujian ANOVA yang menunjukkan bahwa tidak dapat perbedaan yang signifikan berdasarkan uji pasang antar masing-masing kelompok. Dengan kata lain dapat dinyatakan bahwa tidak terdapat pengaruh antara kelompok kontrol dengan kelompok perlakuan. Dengan demikian hipotesis $\mathrm{Ha}$ dalam penelitian ini yang menyatakan bahwa "air alkali terionisasi efektif menurunkan kadar asam urat pada mencit jantan mus muculus " di tolak.Pembuatan Ekstrak buah belimbing wuluh (Averrhoa bilimbi L)

\begin{tabular}{|c|c|c|c|c|}
\hline \multirow{2}{*}{ kelompok } & \multicolumn{4}{|c|}{ Kadar Asam Urat Darah Mencit (mg/dl) } \\
\cline { 2 - 5 } & Tikus 1 & Tikus 2 & Tikus 3 & $\begin{array}{c}\text { Rata-rata \% } \\
\text { penurunan }\end{array}$ \\
\hline $\mathrm{k}-$ & 25.8 & 37 & 29.5 & $0.97 \%$ \\
\hline $\mathrm{K}+$ & 24.1 & 24.2 & 40.2 & $0.68 \%$ \\
\hline $\mathrm{Ph} 8.5$ & $22 . .9$ & 27.8 & 24.8 & $0.93 \%$ \\
\hline $\mathrm{Ph} 9.0$ & 524.6 & 23.3 & 32 & $0.96 \%$ \\
\hline $\mathrm{Ph} 9.5$ & 36.1 & 24.5 & 36.1 & $0.93 \%$ \\
\hline $\mathrm{Ph}$. 11.5 & 34.3 & 30.4 & 22.5 & $0.72 \%$ \\
\hline
\end{tabular}

Hasil uji anova dan uji post hoc test ditolak akan tetapi hasil pengukuran persentasi antar kelompok kontrol dengan kelompok perlakuan terdapat perbedaan secara signifikan pada kelompok control negative hasil persentase penurunan yang didapatkan dari persen penurunan rata-rata data akhir dibagi dengan rata-rata awal lalu dikali dengan $100 \%$ kemudian hasil persen penurunan pada kelompok kontrol negatif pada reflikasi mencit 1 hasilnya $0.98 \%$, mencit $20.97 \%$ dan mencit 3, sebesar $0.96 \%$. Hasil penurunan mencit 1 sampai mencit 3 dijumlahkan lalu dibagi tiga untuk mengetahui rata-rata persen penurunan hasilnya adalah $0.97 \%$.

Pada kelompok kontrol positif hasil persentase penurunan yang didapatkan dari persen penurunan rata-rata data akhir dibagi dengan rata-rata awal lalu dikali dengan $100 \%$ kemudian hasil persen penurunan pada kelompok control positif pada reflikasi mencit 1 hasilnya $0.67 \%$, mencit 2 yaitu $0.74 \%$, dan mencit 3 sebesar $0.65 \%$. hasil penurunan mencit satu sampai dengan mencit tiga 
dijumlahkan lalu dibagi tiga untuk mengetahui rata-rata persen penurunan hasilnya adalah $0.68 \%$.

Pada kelompok perlakuan air alkali $\mathrm{pH}$ 8.5 hasil persentase penurunan yang didapatkan dari persen penurunan rata-rata data akhir dibagi dengan rata-rata awal lalu dikali dengan $100 \%$ kemudian hasil persen penurunan pada kelompok $\mathrm{pH} 8.5$ pada reflikasi mencit 1 hasilnya $0.83 \%$, mencit 2 yaitu $0.98 \%$, dan mencit 3 sebesar $0.98 \%$. Hasil penurunan mencit satu sampai dengan mencit tiga dijumlahkan lalu dibagi tiga untuk mengetahui rata-rata persen penurunan hasilnya adalah $0.93 \%$

Pada kelompok perlakuan air alkali $\mathrm{pH}$ 9.0 hasil persentase penurunan yang didapatkan dari persen penurunan rata-rata data akhir dibagi dengan rata-rata awal lalu dikali dengan $100 \%$ kemudian hasil persen penurunan pada kelompok $\mathrm{pH} 9.0$ pada reflikasi mencit 1 hasilnya $0.96 \%$, mencit 2 yaitu $0.97 \%$, dan mencit 3 sebesar $0.96 \%$. Hasil penurunan mencit satu sampai dengan mencit tiga dijumlahkan lalu dibagi tiga untuk mengetahui rata-rata persen penurunan hasilnya adalah $0.96 \%$.

Pada kelompok perlakuan air alkali $\mathrm{pH}$ 9.5 hasil persentase penurunan yang didapatkan dari persen penurunan rata-rata data akhir dibagi dengan rata-rata awal lalu dikali dengan $100 \%$ kemudian hasil persen penurunan pada kelompok $\mathrm{pH} 9.5$ pada reflikasi mencit 1 hasilnya $0.92 \%$, mencit 2 yaitu $0.94 \%$, dan mencit 3 sebesar $0.95 \%$. Hasil penurunan mencit satu sampai dengan mencit tiga dijumlahkan lalu dibagi iga untuk mengetahui rata-rata persen penurunan hasilnya adalah $0.93 \%$.

Pada kelompok perlakuan air alkali $\mathrm{pH}$ 11.5 hasil persentase penurunan yang didapatkan dari persen penurunan rata-rata data akhir dibagi dengan rata-rata awal lalu dikali dengan 100\% kemudian hasil persen penurunan pada kelompok $\mathrm{pH} 11.5$ pada reflikasi mencit 1 hasilnya $0.64 \%$, mencit 2 yaitu $0.73 \%$, dan mencit 3 sebesar $0.8 \%$. Hasil penurunan mencit satu sampai dengan mencit tiga dijumlahkan lalu dibagi tiga untuk mengetahui rata-rata persen penurunan hasilnya adalah $0.72 \%$.
Dari hasil perhitungan persen penurunan antar kelompok dapat disimpulkan bahwa mencit yang diberikan air alkali terionisasi $\mathrm{pH} 11.5$ secara oral menunjukkan perubahan kadar asam urat dengan rata-rata awal 6.4 dengan rata-rata akhir 5.81 menghasilkan $0.72 \%$ penurunan yang signifikan dibandingkan dengan $\mathrm{pH}$ yanglain.Kesimpulan

Berdasarkan penelitian yang dilakukan dapat disimpulkan bahwa:

1. Air Alkaliterionisasi mempunyai aktifitas anti hiperurisemi/gout ini

2. Aktifitas tersebut pada $\mathrm{pH}$ yang digunakan (pH. 11.5) dengan perhitungan penurunan sebesar $0,72 \%$ jika dibandingkan dengan ph yang lain. Saran

Adapun saran dari penelitian ini adalah sebagai berikut:Perlu dilakukan penelitian lebih lanjut dengan membandingkan kadar asam urat darah dengan menghitung jumlah kadar asam urat yang diekskresikan melalui urine.

1. Perlu dilakukan penelitian lebih lanjut perbandingan efektivitas air alkali merek yang satu dengan yang lain.

\section{DAFTAR PUSTAKA}

Akporiaye, ET, 2009. Basic \& Clinical Pharmacology. 11th ed. Katzung BG, editor. McGraw-Hill Medical;

Aminah, M. S. 2012 Ajaibnya Terapi Herbal Tumpas Penyakit Asam Urat Lebih Aman, Mudah Dan Berkhasiat Dunia Sehat. Jakarta: Niaga Swadaya.

Andri, W.Y.2007. Produksi Mencit Putih $(\mathrm{Mu}] \mathrm{s}$ musculus) dengan substitusi bawang putih (Allium sativum) dalam Ransum, Skripsi. Fakultas peternakan Institusi Pertanian Bogor. P.3-5.

Anief, Moh. 2005. Ilmu Meracik Obat. Gadjah Mada University Press, Jogjakarta.

Anonim. 1979. Farmakope Indonesia, Edisi III. Departemen Kesehatan Republik Indonesia, Jakarta.Syamsuni, 2006. Ilmu Resep. EGC, Jakarta.

Arifin. 2013. Bagaimana Menggunakan Air Kangen yang Baik [Internet]. (Diacu 2015 Mei 12). Tersedia pada: http://hidupsehatenagic.com/bagaimana 
menggunakan-air-kangen-yang-

baik.html.

Aryanti, R, dkk. 2007. Pengaruh Pemeberian Infusa Daun Salam Terhadap Penurunan Kadar Asam Urat Darah Mencit Putih Jantan Yang Di Induksi Dengan Potassium Oksanat. Jurnal, pharmacon, vol.8, 20,

Asaidi, M., 2010, Waspadai Asam Urat, Diva Press, Yogyakarta.

Astari, E. Y. 2008. Pengaruh Pemberian Decocta Daun Dewa Terhadap Penuruna Kadar Asam Urat Serum Pada Mencit Putih Jantan Galur Balb-C Hiperurisemia. Skripsi. Surakarta: Fakultas Farmasi Universitas Muhammadiyah Surakarta.

BPOM.2017. Badan Pengawas Obat Dan Makanan RI, Air Minum Kemasan. Akses, Jumaat, 20 September 201918:49:47.

Edy, S, dkk, 2008. Efektivitas Konsumsi Air Alkali Terhadap Penurunan Kadar Gula Darah Acak Pada Penderita Diabetes Militus Tipe 2. Jurnal keperawatan. Hal 10-21

Fauci AS, dkk. 2008. of Internal Medicine. 17th ed. McGraw-Hill Companies;

Gunawan, SG, dkk. 2007. Departemen Farmakologi dan Terapeutik Fakultas Kedokteran Universitas Indonesia. Farmakologi dan Terapi. 5th ed, editors. Jakarta: Badan Penerbit FKUI;

Hidemitsu H. 2010 "Benefits of alkaline, ionized water". Japan: Water Institute of Japan;. hal 3,4

Lebang E. 2015. Detoksifikasi: Membuang Tumpukan Racun Tubuh Secara Holistik. Jakarta (ID): Mizan Publishing.

Murray RK, dkk. 2006. Harpers Illustrated Biochemistry. 27th ed. Papadakis MA, McPhee SJ, editors. The McGraw-Hill Companies;

Riskesdas 2013. Riset Kesehatan Dasar. Jakarta: Balitbang Kemenkes RI

Rosa MCI, dkk. 2012. Clinical effect and mechanism of alkaline reduced water. Journal of Food and Drug Analysis.; 1(20):394-97.

Satia D. 2015. Manfaat Kangen Water Dalam Kehidupan Sehari-hari [Internet]. (diakses $2015 \quad$ Mei 12) http://enagickangenwater.co.id/kangenwater/manfaat.

Septiandu, I, dkk, 2017. Pengaruh Pemberian Air Alkali Terhadap Kadar Kolesterol Total Pada Tikus Putih Jantan Galur Sprague Dawley. Jurnal farmagazine. Vol.1v. no 2. Hal 38-42

Shamley. D., 2005, Pathophysiology An Essential Text for the Allied Health Professions, Elsevier

Shirahata S, dkk. 2012. Advanced research on the health benefit of reduced water. Trends in Food Science and Technology. Elsevier Ltd; ;23 (2):124-31 Stroke, Yogyakarta, A+Plus Books

Soeroso J, dkk. 2011. Asam urat. Jakarta: Penebar Plus.

Utami, P., 2003, Tanaman Obat untuk Mengatasi Rematik dan Asam Urat, Agromedia Pustaka, Jakarta.

WHO. (2013). Gout dan Asam Urat. 